\title{
Virucidal Activity of the Antiseptic Mouthwash and Dental Gel Containing Anionic Phthalocyanine Derivative: In vitro Study
}

\author{
Caique Santos, (iD) \\ Bernardo da Fonseca Orcina, (iD ${ }^{2}$ \\ Verônica Caroline Brito Reia, ${ }^{2}$ \\ Lucas Gabriel Ribeiro, ${ }^{3}$ \\ Rejane MT Grotto, ${ }^{3}$ Aruã Prudenciatti, ${ }^{3}$ \\ Leonardo Nazario de Moraes, ${ }^{3}$ \\ Mariana Ragghianti Zangrando,' \\ Fabiano Vieira Vilhena, (iD ${ }^{4}$ \\ Paulo Sérgio da Silva Santos (iD) ${ }^{2}$ \\ 'Bauru School of Dentistry, University of \\ São Paulo, Periodontics, Bauru, Brazil; \\ ${ }^{2}$ Bauru School of Dentistry, University of \\ São Paulo, Department of Surgery, \\ Stomatology, Pathology and Radiology, \\ Bauru, Brazil; ${ }^{3}$ Botucatu Medical School, \\ São Paulo State University (UNESP), \\ Botucatu, Brazil; ${ }^{4}$ TRIALS - Oral Health \& \\ Technologies, Bauru, Brazil
}

Video abstract

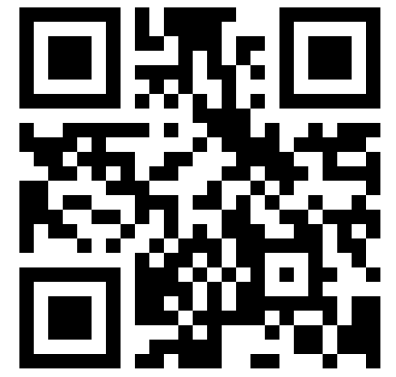

Point your SmartPhone at the code above. If you have a $Q R$ code reader the video abstract will appear. Or use: https://youtu.be/4]c6fuflwms

Correspondence: Paulo Sérgio da Silva Santos

Department of Surgery, Stomatology, Pathology and Radiology - Bauru School of Dentistry - University of Sao Paulo, Al. Dr.Octávio Pinheiro Brisolla, 9 -75, Bauru,

São Paulo, I7012-90I, Brazil

$\mathrm{Tel}+55$ I4 $99670-092$ ।

Email paulosss@fob.usp.br
Aim: This research suggested an in vitro virucidal action of a dental gel and a mouthwash with phthalocyanine derivative.

Purpose: The aim of this study was to report an in vitro study evaluating the virucidal capacity of mouthwash and dental gel containing anionic phthalocyanine derivate (APD).

Methods: The research followed the recommendations of the National Health Surveillance Agency (ANVISA) and adapted methodology, described in the standards EN14776: 2015; ASTM E1053-11 and the Robert Koch Institute - RKI, in addition to good laboratory practices (GLP). The determination of the percentage of inactivation of the SARS-CoV-2 virus particles was carried out by imposing the viral solution in contact with the respective tested products, with intervals of 30 seconds, 1 and 5 minutes, with subsequent submission of the aliquots, recovered in cell culture microplates following virus titration using the TCID50 (50\% Median Tissue Culture Infectious Dose).

Results: The Mouthwash APD presented $90 \%$ of viral inactivation percentage, while the dental gel APD demonstrated $99.99 \%$ of viral inactivation.

Conclusion: In vitro analyses showed that mouthwash and dental gel APD can reduce the viability of SARS-CoV-2 virus particles.

Keywords: mouthwash, dentifrices, coronavirus infections, in vitro techniques

\section{Introduction}

Phthalocyanines are chemical compounds widely used as photosensitizing dyes in photodynamic therapy (PDT). The antimicrobial property of phthalocyanines has been demonstrated in several in vitro studies in the literature, whether associated with PDT against $C$. albicans or in its free form against $S$. mutans, also including antibiofilm action. ${ }^{1-3}$ This characteristic is based on the good adhesion of this molecule to microbial cells, as well as the changes caused in the cellular components of microorganisms. Recently, our research group found in vitro intense antiviral activity of anionic phthalocyanine derivative (APD) against SARS-CoV2 in non-cytotoxic concentrations. ${ }^{4}$

The infection by SARS-CoV-2 occurs by transmission through human saliva possibly when talking, coughing, sneezing or even breathing and droplets formed may contain microorganisms. Each cough can produce 3000 droplets of saliva, which is similar to 5 minutes of conversation with another person. ${ }^{5}$ This is the reason why the oral cavity is linked not only in the infection but also in the 
transmission of COVID-19. ${ }^{6}$ The most common receptor involved in this relationship is the Angiotensin-Converting Enzyme 2 (ACE-2) which is present in high concentrations in the lungs, myocardial and renal cells, as well as in the oral mucosa, especially in the tongue and salivary glands, the latter being identified as a virus reservoir. ${ }^{7,8}$

The pathophysiology of the COVID-19 itself highlights the importance of effective measures in the early stages of the disease, considering that in the first week of infection, individuals present their symptoms in the upper respiratory tract. ${ }^{9,10}$ On the other hand, many of the infected individuals showed symptoms and even neurological sequels, and this is suggested by the entry of SARS-CoV-2, present in the oral or nasal mucosa, in the central nervous system, showing how the severity of the disease. ${ }^{11}$

Therefore, the objective of this in vitro study was to test a mouthwash and a dental gel both containing a phthalocyanine derivative in the possible inactivation of SARS-CoV-2.

\section{Materials and Methods}

\section{Virucidal Activity Tests}

\section{About Human Coronavirus Strains Tested}

In vitro virucidal tests: samples of SARS-CoV-2 were used from oropharyngeal samples of patients diagnosed with the new coronavirus previously expanded in Vero ATCC cell culture ${ }^{\circledR}$ CCL-81 $1{ }^{\mathrm{TM}}$.

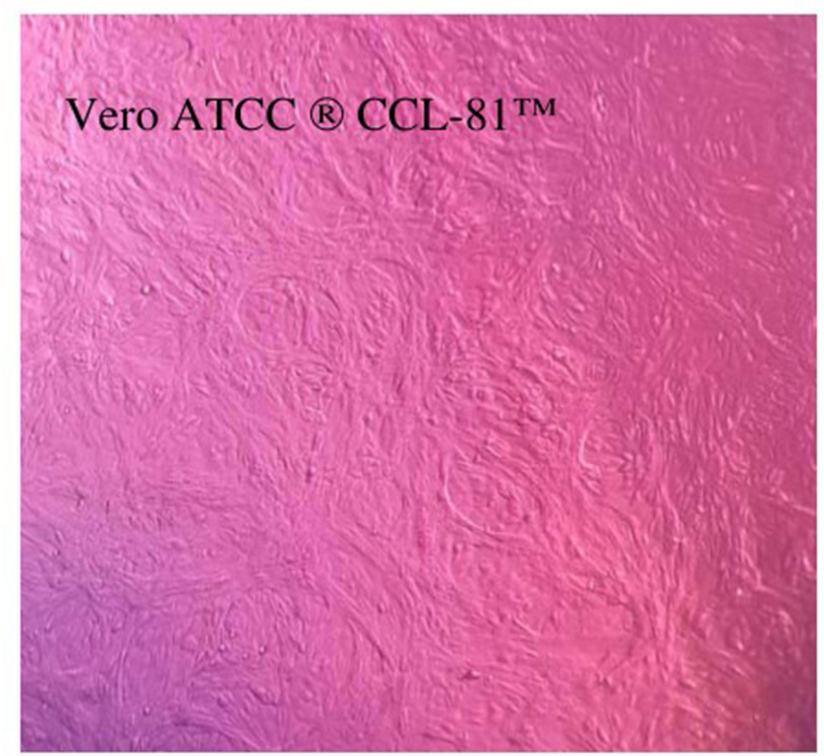

\section{Cell Culture and Virus Cultivation}

The Vero ATCC ${ }^{\circledR}$ CCL-81TM cells were maintained Dulbecco's Modified Eagle's Medium cultivation with $10 \%$ bovine fetal serum in an incubator at $37^{\circ} \mathrm{C}$ and $5 \%$ $\mathrm{CO}_{2}$. The SARS-CoV-2 virus was previously cultured in Vero cell and later was titrated according to the plate assay method, in addition to the determination of viral load by means of an RT-qPCR calibration curve (Figure 1).

\section{Determination of the Maximum Non-Cytotoxic Concentration of the Products}

To determine the concentration of the product to be tested, which does not cause toxicity to the cells, the limit dilution method (end-point-dilution) was used, the methodology involves the inoculation of successive dilutions (pure compound up to $10^{-8}$ dilutions) of the compounds, in Vero ATCC ${ }^{\circledR}$ CCL- $81^{\mathrm{TM}}$, in which it is possible to determine the cytotoxic effect in $50 \%$ of the cells in culture $\left(\mathrm{TCID}_{50}\right)$. The assay was conducted in microplates of 96 wells, flat and sterile bottom, in which $2 \times 10^{5}$ Vero 81 cells per well and $200 \mu \mathrm{L}$ of DMEM (Dulbecco's Modified Eagle's Medium) were added supplemented with 2\% bovine fetal serum and $1 \%$ antibiotic-antimycotic. Thus, the microplates were incubated at $37^{\circ} \mathrm{C}$ in a greenhouse with $5 \% \mathrm{CO}_{2}$ for 72 hours.

In order to determine concentrations of the products that did not cause cytotoxic effect and that could not provide incongruous interpretations to distinguish artifacts from cytopathic and cytotoxic effects, it was observed that

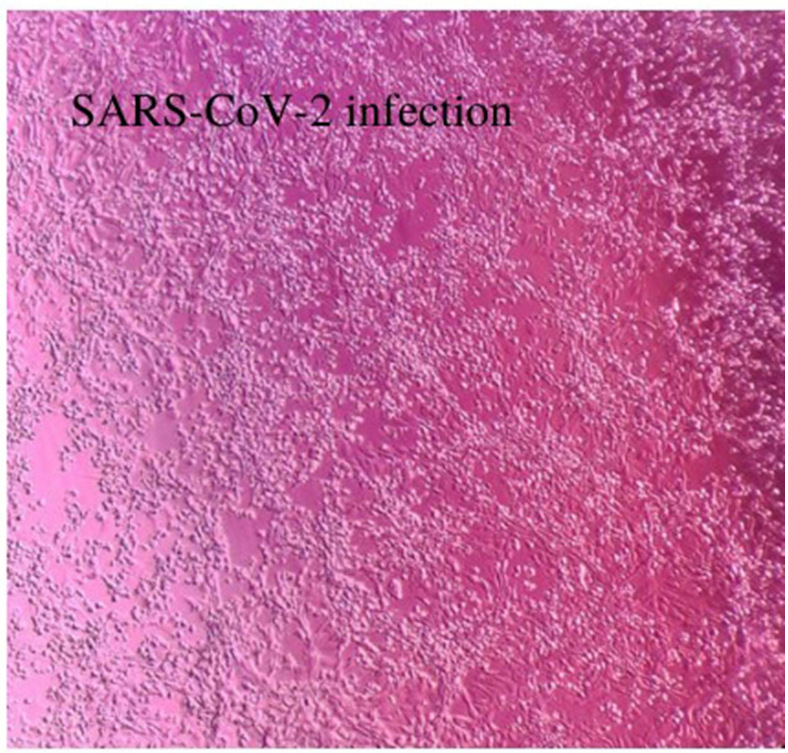

Figure I SARS-CoV-2 infection in cell culture. On the left, an uninfected cell line; on the right: SARS-CoV-2 infection in cell culture of Vero ATCC CCL-8I (Fiocruz, BR). 
for the Mouthwash $0.1 \%$ APD and Dental Gel 1\% APD would be necessary a prior dilution. As the dilution factor varies from -1 to -1 , on a logarithmic scale at base 10 , the dilution factor -2 was considered to perform the assays using the Mouthwash $0.1 \%$ APD, and dilution factor -3 was considered to Dental Gel 1\% APD assays, to be exposed in contact with the cells. All dilutions are considered to apply the calculations of the viral title after exposure of the products with the virus, highlighting that for the contact of the products with the viral solution. After the time of exposure of the viral solution and mouthwash or dental gel is considered the dilution that does not result in toxic effect to the cells.

\section{Virucidal Activity Test}

The experiment was carried out following good laboratory practices (GLPs), methodologies described and adapted according to the standards, EN 14476 (Chemical disinfectants and antiseptics - Quantitative suspension test for the evaluation of virucidal activity in the medical area). ${ }^{12}$ The dental gel and the mouthwash containing ADP were manufactured and provided by TRIALS - Oral Health \& Technologies.

\section{Virucidal Effect Test with Product Contact with SARS-CoV-2 Solution and TCID 50}

The virucidal activity assays were performed in three times (30 seconds, 1 and 5 minutes) of exposure and contact of the products (Dental Gel 1\% APD, Mouthwash $0.1 \%$ ) with the viral solution of SARS-CoV2. It is emphasized that a microplate of 96 wells had been used for each compound and the respective contact times (Figure 2). From these samples, dilutions of the viral solution at base 10 were made in replicates in sterile microplates of 96 wells, in dilution factors from $10^{-1}$ to $10^{-8}$, and dilutions were conducted with DMEM (Dulbecco's Modified Eagle's Medium) with 2\% of bovine serum (inactivated). Microplates in desired confluence of Vero ATCC ${ }^{\circledR}$ CCL-81 ${ }^{\text {TM }}$ with a concentration of $2 \times 10^{5}$ cells/well with DMEM (Dulbecco's Modified Eagle's Medium) with $2 \%$ bovine fetal serum (inactivated) were prepared for the dilutions of the assays of different contact times of the product. The microplates were incubated in an incubator with $5 \% \mathrm{CO}_{2}$ for one hour under agitation, so that viral adsorption occurred. Subsequently, each microplate well was washed with $200 \mu \mathrm{L}$ of buffered saline solution (PBS), with consequent addition of $200 \mu \mathrm{L}$ DMEM (Dulbecco's Modified Eagle's Medium) with 2\% bovine fetal serum (inactivated) and 1\% antibiotic-antimycotic. For positive control, only the viral solution and the previously specified cell concentration were used. The microplates containing the viral solution after contact with the products and cell system were incubated at $37^{\circ}$ $\mathrm{C}$ in an incubator with $5 \% \mathrm{CO}_{2}$ for 72 hours, after this

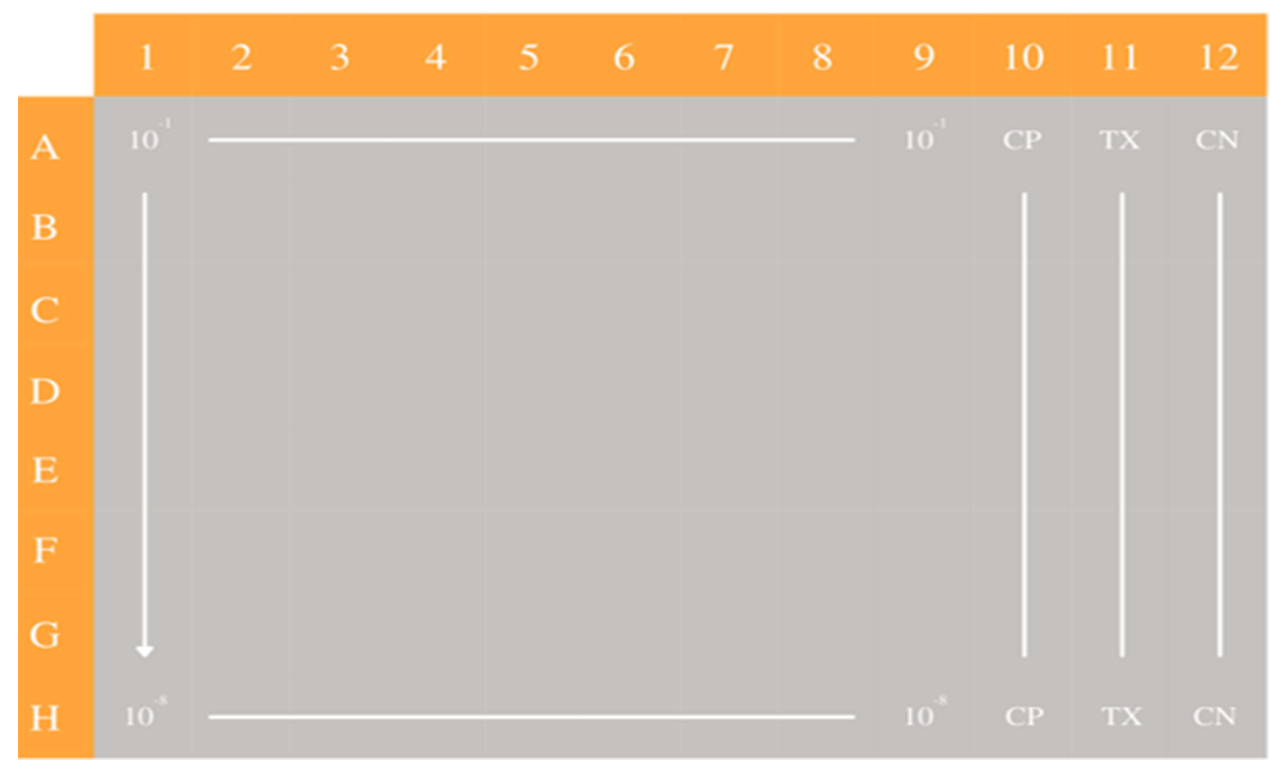

Figure 2 Titration plate scheme: $\operatorname{TCID}_{50}$ (Median Tissue Culture Infectious Dose), performed in microplate of 96 wells, where in the first line were added 9 wells with virus samples in a dilution equal to $10^{-1}$, in the second line a dilution equal to $10^{-2}$ and so on, up to line 8 with dilution of $10^{-8}$. In column 10 , positive control (CP) was added, in which Vero 81 cells were infected with viral solution, in column II (TX) only the MouthWash 0.1\% APD or Dental Gel I\% APD (dilution that does not cause cytotoxic effect) was added with cells and culture medium, and in column 12 all wells were treated only with cells and culture medium (Negative Control - CN). 
interval was evaluated by optical microscopy whether there was cytopathic effect.

\section{Results}

The experimental groups were:

1. Positive Control: Only the viral solution and cellular system

2. Negative Control: Cellular system only

3. Treatment 1: Cellular system, Viral solution and Dental Gel APD (dilution without cytotoxic effect)

4. Treatment 2: Cellular system, Viral solution and Mouthwash APD (dilution without cytotoxic effect)

The determination of the virucidal activity of the product is carried out according to the Methodology TCID $_{50}$ (Median Tissue Culture Infectious Dose). The protocol considers the cultivation of the host cell lines of the virus - Vero ATCC cells ${ }^{\circledR}$ CCL- $81^{\mathrm{TM}}$ in culture microplates of 96 wells with subsequent dilution of the viral solution and the possible virucidal compound to be analyzed.

To evaluate the cytopathic effect, analyses are performed by means of an inverted microscope after an incubation period of 72 hours in an oven at $37^{\circ} \mathrm{C}$ with $5 \%$ $\mathrm{CO}_{2}$. Thus, visual confirmation of the cytopathic effect of SARS-CoV-2 strains is obtained in relation to the Vero ATCC cell ${ }^{\circledR}$ CCL- $81^{\mathrm{TM}}$. The interpretation is based on the method of Spearman \& Karber (Lorenz \& Bögel, 1973). ${ }^{13}$ The result of virucidal efficacy is given as negative when the visualization of cytopathic and positive effects occurs when there is no cytopathic effect. The logarithmic difference between the control group and the group with the treatments is used to determine the viral inhibition index (Table 1). ${ }^{14}$

To quantify the virus obtained in the incubation process, the end-point-dilution methodology was applied (Table 2).

Table I Numerical Analysis of Viral Inactivation

\begin{tabular}{|l|c|c|}
\hline $\begin{array}{l}\text { Reduction } \\
\text { Log }\end{array}$ & $\begin{array}{c}\text { Reduction } \\
\text { Factor }\end{array}$ & $\begin{array}{c}\text { Inactivation } \\
\text { Percentage }\end{array}$ \\
\hline 1 & 10 & $90 \%$ \\
2 & 100 & $99 \%$ \\
3 & 1000 & $99.9 \%$ \\
4 & 10,000 & $99.99 \%$ \\
\hline
\end{tabular}

Note: Obtained in https://microchemlab.com/information/log-and-percent-reduc tions-microbiology-and-antimicrobial-testing.
Table 2 SARS-CoV-2 Viral Titer After Exposure to Products: Mouthwash 0.1\% APD and Dental Gel I\% APD

\begin{tabular}{|l|c|c|}
\hline Products & $\begin{array}{c}\text { Viral Titer of SARS- } \\
\text { CoV-2 (TCID50/mL) }\end{array}$ & $\begin{array}{c}\text { Incubation } \\
\text { Time }\end{array}$ \\
\hline $\begin{array}{l}\text { Positive control } \\
\text { (without any product) }\end{array}$ & $10 \mathrm{E}+5.5$ & - \\
\hline Dental Gel APD I\% & $10 \mathrm{E}+1.5$ & 30 seconds \\
APD & & 5 minute \\
& & 30 seconds \\
I minute \\
Mouthwash 0.1\% APD
\end{tabular}

From this methodology with inoculation of successive increasing dilutions in viral suspension in susceptible cells it is possible to identify the cytopathic effect in $50 \%$ of inoculated cultures. Table 3 demonstrates the percentage of viral inactivation by calculating Reed \& Münch end point calculation method (Reed \& Münch, 1938). The correction factor related to the dilution volume of the virus (SARSCoV-2) used in each TCID $_{50}$ was also applied.

According to the experimental design used and considering that the results are presented as a percentage of viral inactivation (Table 3 ) in comparison with the positive control (viral solution without any product), it was found that the Dental Gel APD 1\% presents 4 reduction logs, with $99.99 \%$ of viral inactivation, and the Mouthwash $0.1 \%$ APD presents 1 reduction $\log$, with $90 \%$ viral inactivation, with the same percentage of reduction for the exposure times performed (30 seconds, 1 minute and 5 minutes) (Figure 3).

\section{Discussion}

Considered a gateway to infectious agents, the oral cavity is directly related to the disease COVID-19, since the

Table 3 Percentage of Viral Inactivation of Mouthwash $0.1 \%$ APD and Dental Gel I\% APD

\begin{tabular}{|l|c|c|}
\hline Products & $\begin{array}{c}\text { SARS-CoV-2 } \\
\text { Inativaction (\%) }\end{array}$ & $\begin{array}{c}\text { Incubation } \\
\text { Time }\end{array}$ \\
\hline $\begin{array}{l}\text { Dental Gel 1\% } \\
\text { APD }\end{array}$ & $99.99 \%$ & $\begin{array}{c}30 \text { seconds } \\
\text { I minute } \\
5 \text { minutes }\end{array}$ \\
\hline Mouthwash 0.1\% & & $\begin{array}{c}30 \text { seconds } \\
\text { I minute } \\
\text { APD }\end{array}$ \\
\hline
\end{tabular}




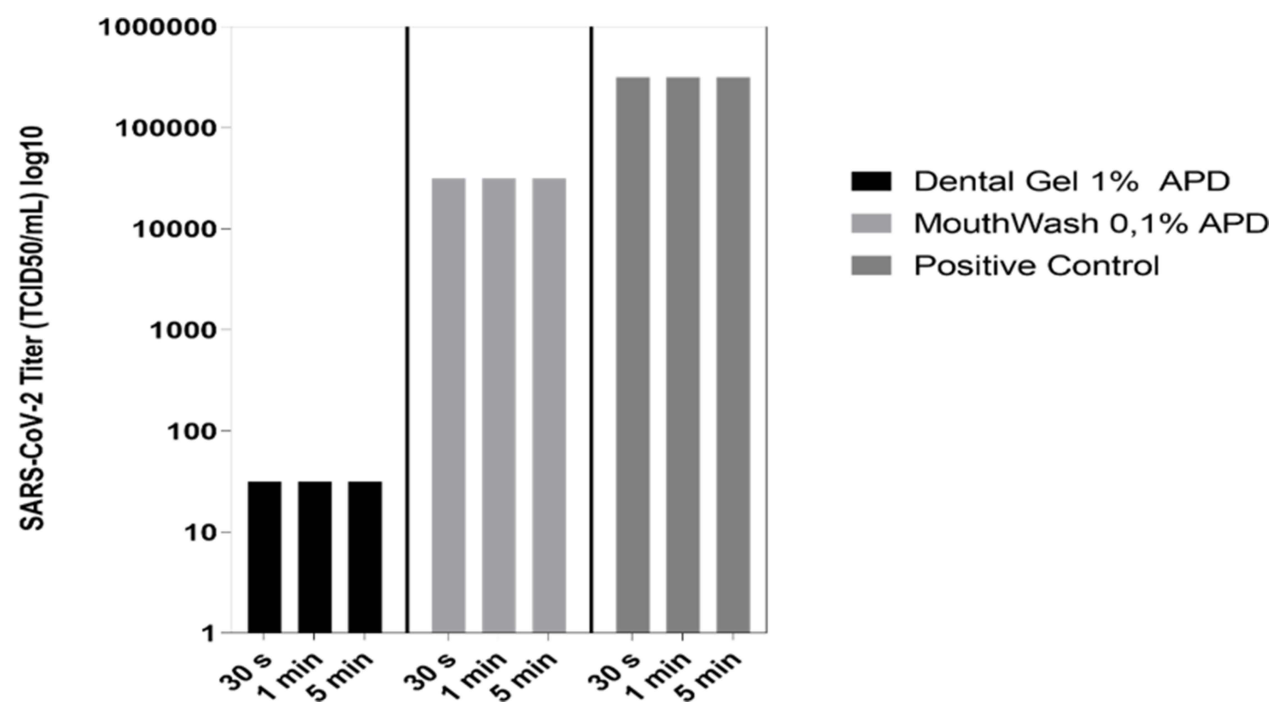

Figure 3 SARS-CoV-2 titer reduction after Mouthwash 0.1\% APD and Dental Gel I\% APD exposure.

spread of the SARS-CoV-2 virus can occur through saliva. $^{15,16}$ The viral load of the oral microbiota has been used as a potent indicator for increasing the severity of the disease and as a consequence, its transmission on a larger scale. ${ }^{17}$ The SARS-CoV-2 virus is vulnerable to oxidation, so rinses containing oxidizing agents work as a viable option for reducing viral load in the oral cavity and oropharynx being widely recommended.

Phthalocyanine is an antimicrobial component that acts by means of visible light causing the selective destruction of viruses, bacteria and other pathogens, used in medical and dental areas, with safe applicability. ${ }^{4}$ The phthalocyanine derivative is a compound with oxidizing properties present in mouthwashes with the principle of promoting self-activation and continuous production of reactive oxygen in the presence of molecular oxygen2. The molecules of this compound are capable of causing oxidative stress to microorganisms, leading to their inactivation and blocking the growth of infectious particles through contact. ${ }^{2,4,6}$ Two case series studies have shown that solutions used for gargling/rinsing with the phthalocyanine derivative contributed to the clinical improvement and general health of individuals infected with COVID-19. ${ }^{10}$ An in vitro study demonstrated a promising antiviral action against SARS-CoV-2 in non-cytotoxic concentrations with efficiency between $92 \%$ and $99 \%$. The same study also reported a significant decrease in hospital stay, to 4 days, with no evolution in the severity of cases, in individuals contaminated by COVID-19 who used $5 \mathrm{~mL}$ of the solution with the phthalocyanine derivative for 1 minute, 5 times a day. This evidence raises the possibility of the benefit for the world population that lacks preventive and therapeutic treatments in the face of this virus and would further enhance its indication as complementary therapy, even helping hospitalized patients. ${ }^{4}$

According to the present study, the use of Mouthwash APD and Dental Gel APD, in maximum and non-cytotoxic concentration, at different times (30 seconds, 1 and 5 minutes) of exposure and contact with the SARS-CoV-2 viral solution, inactivated viral load by $90 \%$ and $99.99 \%$, respectively, compared to the positive control, which corroborates the results of previous studies. $4,10,17$

Promising results are found in this study with the use of phthalocyanine derivatives in the form of a mouthwash and dental gel to reduce the viability of virus particles in vitro, suggesting that they may be useful in reducing transmission, aid in adjuvant treatment and prevention of contamination by COVID-19.

\section{Conclusion}

Testing the Mouthwash APD against SARS-CoV-2 demonstrated virucidal activity within 30 seconds. According to in vitro study and after the exposure time was shown that Mouthwash APD reduce about $90 \%$ of SARS-CoV-2 viral particles. In addition, the Dental Gel APD was also active against SARS-CoV-2 as $99.99 \%$ of viral inactivation within 30 seconds.

\section{Acknowledgments}

To CROP Biotechnology for the experimental design and execution. This study was financed in part by the 
Coordenação de Aperfeiçoamento de Pessoal de Nível Superior (CAPES), Brazil (Finance Code 001).

\section{Author Contributions}

All authors contributed to data analysis, drafting or revising the article, have agreed on the journal to which the article will be submitted, gave final approval of the version to be published, and agree to be accountable for all aspects of the work.

\section{Disclosure}

Dr Vilhena reports personal fees from TRIALS Inc, during the conduct of the study; in addition, Dr Vilhena has a patent classified pending. Dr da Silva Santos reports grants from CNPq process $n^{\circ}$. 309525/2018-7. The other authors claim there are no conflicts of interest.

\section{References}

1. Di Palma MA, Alvarez MG, Ochoa AL, Milanesio ME, Durantini EN. Optimization of cellular uptake of zinc (II) 2, 9, 16, 23-tetrakis [4-(Nmethylpyridyloxy)] phthalocyanine for maximal photoinactivation of Candida albicans. Fungal Biol. 2013;117(11-12):744-751. doi:10.1016/j.funbio.2013.09.001

2. Teodoro G, Santos C, Campos MA, et al. PHTALOX ${ }^{\circledR}$ antimicrobial action and cytotoxicity: in vitro Study. $J$ Dent Res. 2020;99(Spec Iss A):abstract number, 0839. IADR/AADR/CADR General Session (Washington, D.C., USA).

3. Santos C, Teodoro G, Sibelino S, et al. Antibiofilm action of PHTALOX ${ }^{\circledR}$-containing oral care formulations. J Dent Res. 2020;99 (Spec Iss A):abstractnumber, 3326. IADR/AADR/CADR General Session (Washington, D.C., USA).

4. Santos PSS, Orcina BF, Machado RRG, et al. Beneficial effects of a mouthwash containing an antiviral phthalocyanine derivative on the length of hospital stay for COVID-19. PREPRINT (Version 1). Research Square; March 16, 2021. doi:10.21203/rs.3.rs-330173/v1.

5. Baghizadeh FM. Oral saliva and COVID-19. Oral Oncol. 2020;108:104821. doi:10.1016/j.oraloncology.2020.104821
6. Carrouel F, Conte MP, Fisher J, et al. COVID-19: a recommendation to examine the effect of mouthrinses with $\beta$-cyclodextrin combined with citrox in preventing infection and progression. $J$ Clin Med. 2020;9(4):1-8. doi:10.3390/jcm9041126

7. Xu J, Li Y, Gan F, Du Y, Yao Y. Salivary glands: potential reservoirs for COVID-19 asymptomatic infection. J Dent Res. 2020;99(8):989. doi: $10.1177 / 0022034520918518$

8. Yan R, Zhang Y, Li Y, Xia L, Guo Y, Zhou Q. Structural basis for the recognition of SARS-CoV-2 by full-length human ACE2. Science. 2020;367(6485):1444-1448. doi:10.1126/science.abb2762

9. Azkur AK, Akdis M, Azkur D, et al. Immune response to SARSCoV-2 and mechanisms of immunopathological changes in COVID19. Allergy. 2020;75(7):1564-1581. doi:10.1111/all.14364

10. da Fonseca Orcina B, Vilhena FV, Cardoso de Oliveira R, et al. A phthalocyanine derivate mouthwash to gargling/rinsing as an option to reduce clinical symptoms of COVID-19: case series. Clin Cosmet Investig Dent. 2021;13:47-50. doi:10.2147/CCIDE.S295423

11. Meinhardt J, Radke J, Dittmayer C, et al. Olfactory transmucosal SARS-CoV-2 invasion as a port of central nervous system entry in individuals with COVID-19. Nat Neurosci. 2021;24(2):168-175. PMID: 33257876. doi:10.1038/s41593-020-00758-5

12. Din EN 14476: chemical disinfectants and antiseptics. Quantitative suspension test for the evaluation of virucidal activity of chemical disinfectants used in human medicine. Test method and requirements without mechanical action (phase 2/step 1). Brussels: CEN - Comité Européen de Normalisation; 2015.

13. Lorenz RJ, Bogel K. Laboratory techniques in rabies: methods of calculation. Monogr Ser World Health Organ. 1973;23:321-335.

14. Reed LJ, Muench H. A simple method of estimating fifty per cent endpoints. Am J Epidemiol. 1938;27(3):493-497. doi:10.1093/ oxfordjournals.aje.a118408

15. Hussain A, Kaler J, Tabrez E, Tabrez S, Tabrez SSM. Novel COVID19: a comprehensive review of transmission, manifestation, and pathogenesis. Cureus. 2020;12(5):e8184. doi:10.7759/cureus.8184

16. To KK-W, Tsang OT-Y, Yip CC-Y, et al. Consistent detection of 2019 novel coronavirus in saliva. Clin Infect Dis. 2020;71(15):841-843. doi:10.1093/cid/ciaa149

17. Orcina BF, Santos PSS. Oral manifestation COVID-19 and the rapid resolution of symptoms post-phtalox treatment: a case series. Int $J$ Odontostomat. 2021;15(1):67-70. doi:10.4067/S0718381X2021000100067
Clinical, Cosmetic and Investigational Dentistry

\section{Publish your work in this journal}

Clinical, Cosmetic and Investigational Dentistry is an international, peer-reviewed, open access, online journal focusing on the latest clinical and experimental research in dentistry with specific emphasis on cosmetic interventions. Innovative developments in dental materials, techniques and devices that improve outcomes and patient satisfaction and preference will be highlighted. The manuscript management system is completely online and includes a very quick and fair peer-review system, which is all easy to use. Visit http://www.dovepress.com/testimonials.php to read real quotes from published authors. 